\title{
Improving the Creative Thinking Skills of Students by Implementing the MOGE Model
}

\author{
$1^{\text {st }} \mathrm{Al}$ Badrotus Tsaniyah \\ Science Education Student, \\ Universitas Negeri Surabaya, \\ Ketintang St., Surabaya 60231, \\ Indonesia \\ Al_bat1978@yahoo.com
}

\author{
$2^{\text {nd }}$ Madlazim \\ Department of Education MIPA, \\ Universitas Negeri Surabaya, \\ Ketintang St., Surabaya 60231, \\ Indonesia \\ madlazim@unesa.ac.id
}

\author{
$3^{\text {rd }}$ Sri Poedjiastoeti \\ Department of Education MIPA, \\ Universitas Negeri Surabaya, \\ Ketintang St., Surabaya 60231, \\ Indonesia \\ sripoedjiastoeti@yahoo.com
}

\author{
$4^{\text {th }}$ Mir'atul Khusna Mufida \\ State Polytechnic of Batam Jl. \\ Ahmad Yani Batam Center \\ Batam Kepulauan Riau \\ Indonesia \\ vda@polibatam.ac.id
}

\begin{abstract}
The current education practice is too focused on academic skills, limiting the learning environment and edutainment point of view. This causes the low level in students' creative thinking skills. The MOGE model is believed to able to improve students creative thinking skills. The MOGE model was conducted on 246 eight grade junior high school students in Mojokerto, East Java, comprising students of class A, B, and C of Roudlotun Nasyiin Junior High School, MTs Roudlotu Nasyi'in, and Kemlagi State Junior High School 1. This is educational research, which employs educational research design. A learning instrument was developed during the operationalization of the model. The obtained data were analyzed using the descriptive quantitative method. The results of the study show an increase in students' creative thinking skills.
\end{abstract}

Keywords_ MOGE learning model, creative thinking skills

\section{INTRODUCTION}

Curriculum development in Indonesia has undergone several changes from 1947 to 2013. The implementation of the 2013 curriculum was based on the evaluation of the 2006 KTSP curriculum. Four standards were revised, i.e. the content, process, assessment, and qualification. The 2013 curriculum aimed to build competent, faithful, productive, creative, and innovative citizens of Indonesia, to contribute to the people, society, nation, and the world in general (Permendikbud no. 104 of 2014).

Creative thinking skills, according to Plucker et al (2015), are one of the 21st century abilities that must be developed. Griffin, McGaw, \& Care (2012) explain that there are ten 21st century abilities that must be learned and mastered. They are classified into four groups: cognition (i.e. creative and innovate thinking, critical thinking, problem-solving, and metacognitive thinking), work (i.e. communication and collaboration), information and communication literacy, and living in the world (socializing (both locally and globally), life and career, and personal and social responsibility (including culture)).

Moreover, from the results of their research, Griffin \& Care (2012) states that there will be a $65 \%$ increase in jobs that require a high level of thinking in 2020. Research by Tsaniyah (2015) shows that students creative thinking skills level is still low because teachers never taught it in the class. This claim is further supported by the absence of activities that may improve creative thinking skills in the learning implementation plan of the teachers. The current learning process is too focused on academic skills, setting aside many other aspects and reducing playing time significantly one of the factors causing the students' low creative thinking skills (Bassok, Latham, \& Rorem, 2016; Gray, 2016).

Craft (2003) explains that creative thinking can be developed using games because they can improve students' imagination, which, in turn, boost their creativity. Furthermore, Jona K. et al (2010) explains that games can facilitate students to communicate their feelings and think creatively. This is also supported by a number of other studies (Dansky \& Silverman, 1973; Howard-Jones, Taylor, \& Sutton, 2002; Moore \& Russ, 2008; Russ \& Schafer, 2006; Saracho, 1992 ).

Based on the above explanations, the researcher considers that it is important to implement a game-based learning model (MOGE model) to enhance students' creative thinking skills.

\section{METHOD}

This research is educational research, which employs educational research design. In the operationalization of the study, a learning instrument was developed. The MOGE model was implemented to 246 eight grade junior high school students in Mojokerto, East Java, comprising students of class A, B, and C of Roudlotun Nasyiin Junior High School, MTs Roudlotu Nasyi'in, and Kemlagi State Junior High School 1. The obtained data were analyzed using the descriptive quantitative method.

The selection of research samples is based on school groups, namely the upper group, middle group, and lower group. Grouping research samples based on student input, school report cards and results of school accreditation.

This development research has five steps to develop models referring to Waderman development model (Akker, et al; 2010) are: 1) problem identification, 2) identification of tentative products and design principles, 3) tentative products and theories, 4) prototyping and assessment of preliminary products and theories, and 5) problem resolution and advancing theory. 


\section{Step 1: problem identification}

In this step the researcher examined literature and theory to learn about creative thinking skills and the relationship between creative thinking skills and games. Researchers also analyzed the latest scientific articles to examine issues related to students' creative thinking skills and the relationship between creative thinking skills and play. Furthermore, the researchers conducted a preliminary study to see the picture of science learning in junior high school which included, lesson plans made by the teacher, the learning process carried out by the teacher, student learning outcomes, and creative thinking skills of junior high school students.

\section{Step 2: Identification of tentative products and design principles}

Based on the results of the analysis of literature and the results of preliminary studies, researchers designed learning models to teach creative thinking skills of junior high school students. The indicators of creative thinking skills in this study are: fluency, flexibility, originality, and elaboration. The learning model developed will be implemented in eighth grade students in the subject matter Pressure and Temperature. The choice of material is adjusted to the characteristics of the material to improve students' creative thinking skills.

\section{Step 3: Tentative products and theories}

In this step, the researcher designed a learning model, namely the MOGE learning model (prototype 1) whose components include: 1) the syntax of the model, 2) the social system, 3) the principle of reaction, 4) the support system, 5) the instructional impact and the accompanying impact. The design of learning models and learning tools developed were realized in the form of a model book which were then validated by experts in a Forum Group Discussion (FGD). The focus of FGD activities was to discuss the validity of theoretically developed learning models that include components of the learning model, namely: 1) model syntax, 2) social systems, 3) reaction principles, 4) support systems, 5) instructional impacts and accompaniment impacts. The results of the FGD activities were used as a reference for revising the MOGE learning model (prototype 2).

\section{Step 4: Prototyping and assessment of preliminary products and theories}

In the fourth step, the researcher implemented the MOGE learning model (prototype 2) in a cycle in class VIII of junior high school which is the research sample. The test was conducted to find out the weaknesses of the implementation of the model in improving students' creative thinking skills. The results of the implementation of the model produced prototype 3.

\section{Step 5: Problem resolution and advancing theory}

In the next step is the process of refining the model that was developed from the results of the trial. The revised results of the trial produced a product that is a MOGE learning model.

Variables related in this study are the validity of the model and the effectiveness of the model in increasing students' creative thinking skills.
The research instrument used to collect data for the assessment of the feasibility of developing learning models is an instrument of validation of learning models and an instrument for evaluating students' creative thinking skills.

This research data collection technique uses: 1) FGD technique, is a discussion forum attended by experts with the aim of validating the learning model, where the results of the FGD will be used as a reference to revise the weaknesses of the MOGE learning model.

The data analysis technique includes the validity analysis of the model and the analysis of the results of students' creative thinking skills.

\section{RESUlT AND DISCUSSIONS}

\section{A. MOGE Model Validation Results}

Validation of the MOGE model developed was carried out by experts in a discussion forum called the Focus Group Discussion (FGD). According to Marelli (2008) FGD is a small group discussion where participants respond to a series of questions focused on one topic.

Based on the results of the FGD obtained the results of the content validity and construct validity of the MOGE model. The results of the content validity of the MOGE model can be seen in Table 1, while the results of the construct validity of the MOGE model can be seen in Table 2.

TABle 1 VALIDITy of CONTENTS OF THE MOGE MOdEL

\begin{tabular}{|c|c|c|c|c|c|}
\hline No. & Aspect of Assessment & $\begin{array}{l}\text { Nochus } \\
\text { Valiadrion } \\
\text { Score }\end{array}$ & Citeria & $\begin{array}{l}\text { Reliability } \\
\text { Coofficient } \\
(\%)\end{array}$ & Reliability \\
\hline 1 & Rational development of lezning model Mogg & 4 & Very Valid & 86 & Reliable \\
\hline 2 & Cumert browledge & 4 & Very Valid & 86 & Reliable \\
\hline 3 & Theoretical and empirical support of $\mathrm{M}$ Kogg & 3 & Valid & 100 & Reliable \\
\hline 4 & Description of the Nogg leaning model & 3 & Valid & 100 & Reliable \\
\hline 5 & Lemning enviroment and classroom management & 4 & Very Valid & 100 & Reliable \\
\hline
\end{tabular}

TABLE 2 THE VALIDITY OF THE MOGE MODEL CONSTRUCTION

\begin{tabular}{|c|c|c|c|c|c|}
\hline No. & Aspect of Assessment & $\begin{array}{l}\text { Modus } \\
\text { Validation } \\
\text { Score }\end{array}$ & Criteria & $\begin{array}{l}\text { Reliability } \\
\text { Coefficient } \\
(\%)\end{array}$ & Reliability \\
\hline 1 & Rational development of learning model Aqge & 4 & $\begin{array}{l}\text { Very } \\
\text { Valid }\end{array}$ & 86 & Reliable \\
\hline 2 & Current lnowwledge & 4 & $\begin{array}{l}\text { Very } \\
\text { Valid }\end{array}$ & 100 & Reliable \\
\hline 3 & Theoretical and empirical support of Moget. & 3 & $\begin{array}{l}\text { Very } \\
\text { Valid }\end{array}$ & 100 & Reliable \\
\hline 4 & Description of the Mgge leaming model & 4 & Valid & 100 & Reliable \\
\hline 5 & Learming environment and classroom management & 3 & Valid & 100 & Reliable \\
\hline 6 & Support system & 3 & Valid & 100 & Reliable \\
\hline 7 & Instructional Impacts and Accompaniment Impacts & 3 & Valid & 100 & Reliable \\
\hline
\end{tabular}

Based on Tables 1 and 2 it can be shown that the results of the content validity and the construct of the model are valid, where the Percentage of agreement shows consistency among experts in expressing the validity of the MOGE model $\geqslant 75 \%$. This shows that the learning model developed has a strong theoretical foundation and components of the learning model with high consistency, so it is valid for use.

\section{B. Student Creative Thinking Skill Test Results}

The results of the implementation of the MOGE model in the learning process can be seen in Table 3. The scores represent the students' creative thinking skills.

Identify applicable funding agency here. If none, delete this text box. 
TABLE III. ThE PRE-TEST AND POST-TEST RESUlt SCORES

\begin{tabular}{|c|c|c|c|c|c|c|c|c|c|c|c|c|c|c|c|c|c|c|c|}
\hline \multirow{4}{*}{$\begin{array}{l}\text { Mean } \\
\text { Scoere }\end{array}$} & \multicolumn{6}{|c|}{ Roeas } & \multicolumn{7}{|c|}{ MTs Ronas } & \multicolumn{6}{|c|}{ Kemlagi 1} \\
\hline & & & & IIB & & IC & & IIA & & IIIB & & IIII & & & IIA & & & & IIIIC \\
\hline & $P_{t}$ & Po & $P_{t}$ & $\mathrm{Po}_{0}$ & $P_{T}$ & $P_{0}$ & Pr & Po & $\operatorname{Pr}_{\mathrm{r}}$ & $P_{0}$ & $\mathrm{Pt}_{\mathrm{t}}$ & & po & Pr & $P_{0}$ & Pr & Po & $P_{T}$ & $\mathrm{Po}_{0}$ \\
\hline & $c$ & st & $c$ & st & $c$ & st & $c$ & st & $c$ & st & $c$ & & st & $c$ & st & $c$ & st & $c$ & st \\
\hline Fluency & 2 & 5 & 2 & 5 & 2 & 4 & 2 & 4 & 1 & 4 & 1 & & 4 & 1 & 4 & 1 & 5 & 1 & 4 \\
\hline Flexibili & 0 & 5 & 2 & 5 & 2 & 6 & 2 & 6 & 1 & 6 & 0 & & 5 & 1 & 6 & 0 & 5 & 0 & 6 \\
\hline Originali & 2 & 4 & 1 & 4 & 1 & 4 & 1 & 5 & 0 & 5 & 0 & & 5 & 2 & 5 & 1 & 5 & 1 & 4 \\
\hline $\begin{array}{c}\text { ty } \\
\text { Elaborat }\end{array}$ & 1 & 5 & 2 & 5 & 1 & 5 & 2 & 5 & 1 & 5 & 1 & & 5 & 2 & 5 & 1 & 5 & 0 & 5 \\
\hline
\end{tabular}

Based on the table, improvements in the average scores of the pre-test and post-test in each indicator of the students' creative thinking skills can be observed. The implementation of the MOGE model in the learning process can increase the skills. The N-gain scores can be seen in Table 4.

TABLE IV. THE N-GAIN SCORES

\begin{tabular}{llllllllllll}
\hline n-gain & \multicolumn{1}{l}{ Ronas } & \multicolumn{4}{c}{ MTs Ronas } & \multicolumn{4}{c}{ Kemlagi 1 } & \multirow{2}{*}{ Mean } \\
& \cline { 2 - 9 } & VIII & VIII & VIII & VIII & VIII & VIII & VIII & VIII & VIII & \\
& A & B & C & A & B & C & A & B & C & \\
\hline Fluency & 0,7 & 0,7 & 0,72 & 0,82 & 0,82 & 0,72 & 0,72 & 0,7 & 0,7 & 0,73 \\
Flexibility & 0,7 & 0,7 & 0,72 & 0,73 & 0,78 & 0,75 & 0,78 & 0,78 & 0,7 & 0,74 \\
Originality & 0,37 & 0,64 & 0,57 & 0,81 & 0,74 & 0,8 & 0,7 & 0,69 & 0,63 & 0,66 \\
Elaboration & 0,63 & 0,67 & 0,7 & 0,73 & 0,8 & 0,77 & 0,7 & 0,72 & 0,8 & 0,72 \\
\hline
\end{tabular}

According to the information in the table, the $\mathrm{n}$-gain means in the fluency, flexibility, and elaboration indicators are 0.73 , 0.74 , and 0.72 respectively, which can be categorized as high. On the other hand, the mean for the originality indicator is 0.66 (medium). The results indicate that the implementation of the MOGE model in the learning process has an impact on the development of creative thinking skills.

\section{DisCUSSIONS ON THE FINDINGS}

\section{A. Content Validation and Construction of the MOGE Model}

The results of the validation of the MOGE model that have been developed have met the validity in content as shown in Table 1 . The novelty of the Moge model was built to correct the weaknesses in the PBL model and the TGT type Cooperative model based on the recommendations of previous researchers. The novelty of the MOGE model compared to the PBL model in practicing creative thinking skills is located in phase 2, namely games. One weakness of the PBL model is that students feel pressured in learning, especially for students whose initial knowledge is not good. The second syntax of the MOGE model is games that reduce the feelings of students who are depressed, because in games all students feel the same and in carrying out learning students will feel comfortable. Feelings of comfort felt by students will increase students' ability to bring out creative ideas. Play activities designed in phase 2 encourage students to be directly involved in eliciting creative ideas in solving problems given and relating to the real world. This will encourage students to improve their creative thinking skills (Freiler, 2008). The stages / syntax of the MOGE model are as follows:

Phase 1 of the MOGE model is motivation and problem orientation. In this phase students are given a phenomenon in the form of problems related to their daily lives. The activity in phase 1 has been able to arouse their motivation which is marked by the increasing curiosity of students towards the material to be studied so as to require students to express their creative ideas (Wallas, 1926). Increased student curiosity is one of the characteristics of creative students (Sattler, 1992).
The game in learning is believed to make learning comfortable and interesting so that students' motivation can increase (Un Acigoz, 2006). The second phase of the MOGE model is the games tournament, which in this phase is divided into three games, namely basic games, intermediate games, da advanced game.

Basic game in phase 2 asks students to compete in providing creative ideas in solving problems related to daily life that have been prepared by the teacher. In this game students get a score from the results of the game that has been done. Students are also asked to evaluate the creative ideas that have been given. Students in groups compete with each other to bring out as many creative ideas as they have. Games according to (Smaldino, et al., 2011; Un Avigoz, 2006; Cristie, 1980; Yawkey, 1980 in Nur, 2004; Kun Chen Tsai, 2015) are able to motivate students and make learning comfortable and interesting, so that children become more flexible in students' thinking and creative performance can improve.

The second game from phase 2 is an intermediate game. In this game students will compete with each other in issuing as many ways as possible to prove their creative ideas in the basic game by choosing the right tools that have been provided. Students in groups will get a score from the method presented and also the selection of tools that have been done. Students are also required to evaluate the methods and tools that have been selected in the intermediate game. Intermediary games can encourage cognitive development and affective processes that are needed for students' creative performance.

The third game of phase 2 is the advanced game. Students are asked to make a product based on the concepts they have. In this game students get scores based on products that have been made and the suitability of the concepts used in making products. This game has been able to increase students' imagination so that they are able to create original products by elaborating on existing concepts. Plucker et al (1999) explain that creative students are able to solve problems and produce a product that is new and has value.

Phase 3 evaluation and awarding. Phase 3 requires students to evaluate each completion of the challenges that have been made. Evaluations conducted by students are able to improve students' mastery of the concepts of physics material learned so that students are able to make products by elaborating concepts they have mastered. Giving awards to the group with the most scores has a positive impact on students, so students will tend to repeat the activity.

\section{B. The Effectiveness of the MOGE Model in Improving Students' Creative Thinking Skills}

The indicators of creative thinking skills used in this study are fluency, flexibility, originality, and elaboration. Each indicator of students' creative thinking skills was assessed using a creative thinking skills test consisting of 8 questions. This test is carried out before the learning process is carried out (pretest) and after the learning process (posttest).

Based on the results of the study it can be explained that there is an increase in students' creative thinking skills indicated by an increase in the posttest scores obtained by 
students and the $\mathrm{N}$-gain of each indicator of creative thinking skills namely each by fluency0.73 with a high category, flexibility 0,74 with a high category, originality 0.66 with a medium category, and elaboration 0.72 with a high category.

Improving students' creative thinking skills on fluent indicators is the impact of implementing the Moge model on the first stage of giving motivation and problem orientation and the second syntax of games tournament. In the first syntax students are motivated by giving questions in the form of a problem related to the real world. able to improve making students to think high level so as to produce ideas / ideas to solve problems (Gulistan et al, 2015). Students' skills in the form of cognitive activity in solving problems are creative thinking skills (Adams, 2005; Pisa, 2012).

The second syntax of the Moge model, the games tournament, on the basic game has also been able to improve creative thinking skills on fluency indicators. Problems given to students, where students are asked to write their ideas in the mine idea column can make students express creative ideas / ideas smoothly. Students learn more effectively when using the environment around them so as to stimulate their sense of light (Wiyanto et al., 2017 ).

The implementation of the Moge model also has an impact on increasing creative thinking skills on the indicator of flexibility. The second syntax of the Moge model in an intermediate game asks students to prove ideas written on a basic game by doing a simple experiment. Kutlu (2015) explains that experimental activities can make students have a positive attitude towards science and develop creative thinking, learning activities must include investigative activities that enable students to conduct investigations while learning (Trendita, Mahanal, Zubaidah; 2016). Students plan the experiments and choose the tools that are appropriate to the experiments conducted. Intermediate games have an impact on improving student skills on the indicator of flexibility.

Improving students' creative thinking skills on the indicators of originality and elaboration is the impact of the syntax of the Moge 2 model in the advanced game, where students are asked to make a product by elaborating concepts that have been understood by selecting the tools and materials that have been provided. Students will imagine by making a drawing design of the product to be made. In the advanced game students are trained to make original products based on their creative ideas.

The indicators used to measure the creative thinking skills in this study are fluency, flexibility, originality, and elaboration. Each indicator was assessed using creative thinking skill test containing eight questions. The test was administered before (pre-test) and after (post-test) the learning process.

The results show the indication of the improvement in the creative thinking skills, which is indicated by the increase in the students' post-test and N-gain scores of each indicator$0.73,0.74$, and 0.72 (high) for fluency, flexibility, and elaboration respectively, as well as 0.66 (medium) for originality.
Phase 1 of the MOGE model is motivation and problem orientation. In this phase, the students were given a phenomenon in the form of a problem related to their daily lives. Activities in phase 1 were capable of arousing their motivation, indicated by an increase in their curiosity about the learning materials, which necessitate them to express their creative ideas (Wallas, 1926). The increased level of curiosity signals the characteristic of a creative student (Sattler, 1992). It is believed that the inclusion of games can make the learning process more interesting and enjoyable, increasing students' motivation (Un Acigoz, (2006). The second phase of the MOGE model is the game tournament, which consists of three games: basic, intermediate, and advanced.

In the basic level, students must argue about the best idea to solve a problem, which has already been predetermined by the teacher, related to their daily life. Scores are earned based on their contributions. They also need to evaluate other's ideas. They must compete with each other to contribute as many creative ideas as they can in groups. Games can motivate students and make the learning process more interesting and enjoyable, so that students can think in a more flexible way and improve the level of creative work (Smaldino, et al, 2011; Un Avigoz, 2006; Cristie, 1980; Yawkey, 1980 in Nur, 2004; Kun Chen Tsai, 2015).

The second game (phase 2) is the intermediate game. In this game, students must support their ideas in the basic game using the right tools that have been provided. They must compete with each other by arguing about the best means and tools for the problem. The scoring is based on both the method and tool selection. Students are also required to evaluate the chosen methods and tools. Intermediate games can stimulate cognitive development and affective process needed for creative work.

The third game from phase 2 is the advanced game. Students are asked to make a product based on their ideas. In this game, scores are given based on the products and their relevance with the ideas. This game requires students to use their imagination to create original products by elaborating on the ideas they have developed. Plucker et al (1999) state that creative students can solve problems and create valuable new products.

Phase 3 involves evaluation and awarding. The phase requires students to evaluate every step in solving the problem. The process can strengthen their previous understanding of the concepts of Physics. They will be able to create products by elaborating on the concepts they have mastered. Giving an award to the group with the most scores has a positive impact on students; they will be more eager to repeat the activity.

\section{CONCLUSION AND RECOMMENDATION}

Based on the results of the study, it can be concluded that the Moge model is declared valid and can be used in improving students' creative thinking skills. 
Some recommendations can be given based on this study. A lot of time must be allocated for the study. Students need to have sufficient background knowledge in order for the learning process to proceed smoothly. Students still also need to be taught on how to reflect on the steps taken.

\section{REFERENCES}

[1] Akker, J.V., Bannan, B., Kelly, A.E,. Nieveen, N., \& Plomp. (2010). An introduction to educational design research. Enshede, the netherlands: SLO.

[2] [1] Gulistan, A.M.S., Siraj, S., Nordin, A.B. \& Amedy, S.O. (2015). Teaching Strategies For Promoting Higher Order Thinking Skills: A Case Of Secondary Science Teachers. Malaysian Online Journal Of Educational Management (MOJEM).: 3(4):16-30

[3] [1] Adams, K. (2005). The Sources Of Innovation On Creativity. A Paper Commsioned by The National Center On Education And The Economy For New Commision on the Skills Of The American Workforce. National Center On Education and The Economy.

[4] [1] Kutlu. (2015). The Effect Of Purdue Model Based Science Teaching On Creative Thinking. International Journal of Education and Research. 3(3): 589-600.

[5] [1] PISA. (2012). Field Trial Problem Solving Framework. (Online), http://www.oecd.org/pisa/pisaproducts/4696200 5.pd, diakses tanggal 26 Juni 2016.

[6] Bassok, D., Latham, S., \& Rorem, A. (2016). Is Kindergarten the New First Grade? AERA Open, 2(1). https://doi.org/10.1177/2332858415616358

[7] Craft. (2003). Creative thinking in the early years of education. Early Years: Journal of international research \& development, 23, 143-154

[8] Dansky, J.L. (1999). Play. in m. a. runco \& s. r pritzker (eds), encyclopedia of creativity (pp. 393-408). San Diego, CA: Academic Press.
[9] Griffin, P., McGaw, B., \& Care, E. (Eds.). 2012. Assessment and teaching of 21 st skills. New York: Springer Publishing Company.

[10] Jona K. Anderson-McNamee. (tt). The importance of play in early chilhood development. Montana State University Extention. www.msuextension. Org

[11] Kemdikbud. 2014. Peraturan menteri pendidikan dan kebudayaan nomor 104 tahun 2014 tentang standar proses. Jakarta. BPSDMPK dan PMP.

[12] Kuen Chen Tsai. 2012. Play, imagination, and creativity: a brief literature review. Journal of education and learning vol.1, no.2. published by canadian center of science and education.

[13] Kuen Chen Tsai. 2012. Play, imagination, and creativity: a brief literature review. Journal of education and learning vol.1, no.2. published by canadian center of science and education

[14] Kuen Chen Tsai. 2015. All wwork and no play makes an adult a dull learner. Journal of education and training. Vol. 2 No. 1.

[15] Nur, M. 2004. Perkembangan selama masa anak-anak. edisi 2. Surabaya: Pusat Sains dan Matematika Sekolah (PSMS) Universitas Negeri Surabaya.

[16] Santrock, J.W. (2011). Child development (12th ed.). New York: McGraw-Hill Companies.

[17] Smaldino, dkk. (2011). Instructional technology \& media for learning. Kencana prenada Media Group. Jakarta.

[18] Sattler. (1992). Assesment of children. (3rd rev). San Diego. Jerome M. Sattler.

[19] Tsaniyah. (2015). Diagnosis kesulitan guru mata pelajaran ipa dalam mengimplementasikan kurikulum 2013. Proceeding diseminarkan di seminar nasional sains Unesa.

[20] Tsaniyah. (2016). Analisis rencana pelaksanaan pembelajaran (rpp) guru mata pelajaran ipa dalam meningkatkan keterampilan berpikir kreatif siswa. Proceeding diseminarkan diseminar nasional sains Unesa. 